\title{
Integrated Pest Management (IPM) of the drug store beetle, Stegobium paniceum (L.), a serious pest of old books
}

\begin{abstract}
Recently (January 2010), we have found that drugstore beetle, Stegobium paniceum (L.), is a serious pest of old books in a religious library in Cracow, Poland. About $80 \%$ old books were found more or less damaged by this pest. As the result of larval activity, many holes and tunnels were formed in damaged books. Some of them were old, some of them were new tunnels with live larvae and pupae. Many characteristic emergence holes of the adults were found in the book bindings. Around books there was an enormous amount of dust as a result of larval feeding activity. Live and dead adults were found around old books and within the library room, especially near windows. The Integrated Pest Management program was suggested to the owners and curator of the library to control infestation and to avoid the continuation of the damage.
\end{abstract}

Key words: drug store beetle, infestation, IPM, old books, Stegobium paniceum.

\section{INTRODUCTION}

Museums contain a wide range of organic materials subject to insect attack. Beetles belonging to the families Anobiidae and Dermestidae and moths belonging to the family Tineidae are major pests of collections in art and natural history museums. A list of commonly damaged materials in museums and their associated pests is given by Schrock (1988).

Old books are subject of attack by anobiids. In 2004, the common furniture beetle, Anobium punctatum (DeGeer), was found to have caused a very serious infestation of books stored in one of the largest libraries in Israel containing about 5 million books. Of them, $7 \%$ of the rare and valuable books were infested or suspected of being infested and required treatment (Wilamowski et al., 2008). Recently (January 2010), we have found the similar infestation of old and rare books in a religious library in Cracow, Poland. However, not the common furniture beetle, but the drugstore beetle, Stegobium paniceum (L.), was found as a serious pest of these books. About $80 \%$ old books in this library were found more or less damaged by this pest.

The paper describes and discusses the damage of old books caused by the drugstore beetle, and lists the suitable treatments within the Integrated Pest Management program 
that were suggested to the owners and curator of the library to control infestation and to avoid the continuation of the damage.

\section{MATERIALS AND METHODS}

A religious library in Cracow, Poland, comprises five big rooms, each with several thousands of books. In three halls there were books that were printed as long ago as the $17^{\text {th }}$ century, and some of them are rare and irreplaceable printings (Fig. 1). Temperature and humidity were not recorded and controlled in the rooms with the book stacks.

An entomological survey was performed in January 2010 aimed to collect developmental stages of the pest, to identify the infestation, and to estimate the extent of the infestation and the damage. Information collected was needed to develop the Integrated Pest Management program to control infestation and to avoid the continuation of the damage.

\section{RESULTS}

Live and dead adults were found around old books, and the library room floor, and especially near a window-sill. Larvae and pupae of the pest were found inside the books (Fig. 2). All developmental stages of pest were collected, and the pest was identified in a laboratory as the drugstore beetle, Stegobium paniceum (L.).

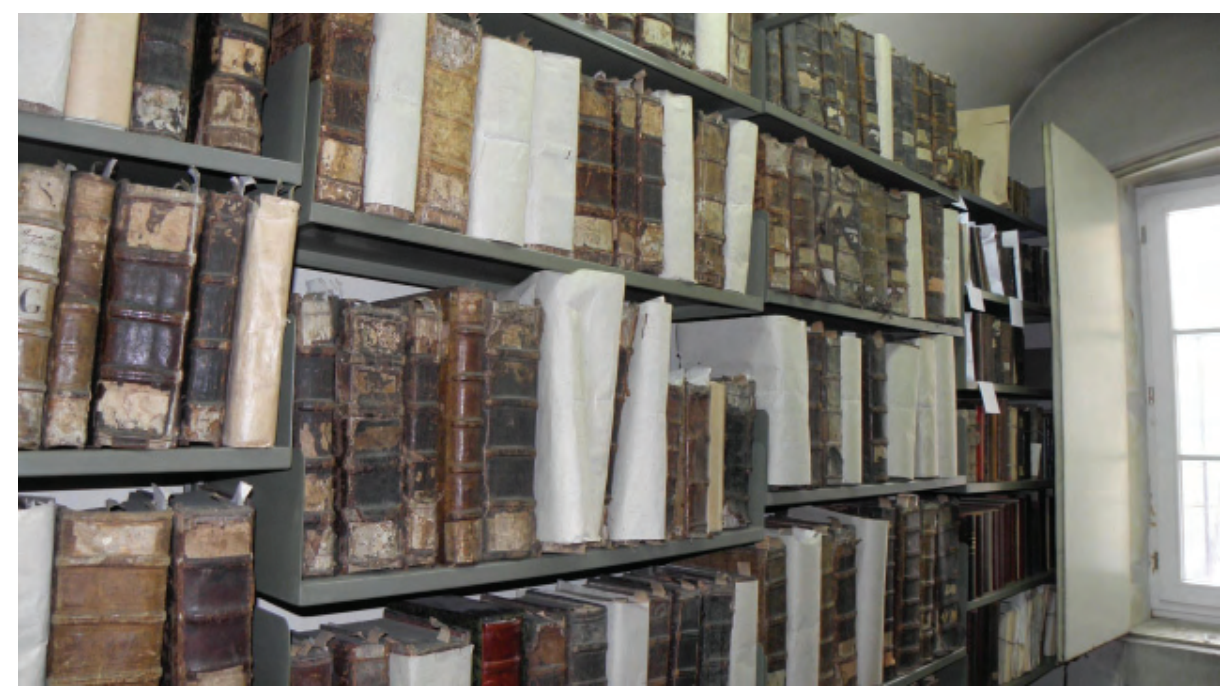

Fig. 1 - Old books in the library room. 
A few larvae, their exuviae, and adults of the varied carpet beetle, Anthrenus verbasci (L.), and some related species were also collected in the library. However, these beetles do not infest books. They are known to feed upon dead insects (Golebiowska \& Nawrot, 1976), including the drugstore beetles.

It was noted that larvae of $S$. paniceum fed on paper and starch glue as they borrowed in book. At the beginning young larvae produced narrow tunnels. With the time, these tunnels become larger as larvae grow. Larvae were found to be specially very active near book binding and/or leather cover of book where they fed on starch glue. After four to six instars, the larvae pupated in large cells located near book binding. Finally, many emergence holes of the adults appeared in book bindings.

As the result of larval activity, many holes and tunnels were found in damaged books. Some of them were old, some of them were new tunnels with live larvae and pupae. Tunnels were of varying shape (Fig. 3), and several dozens of book pages were

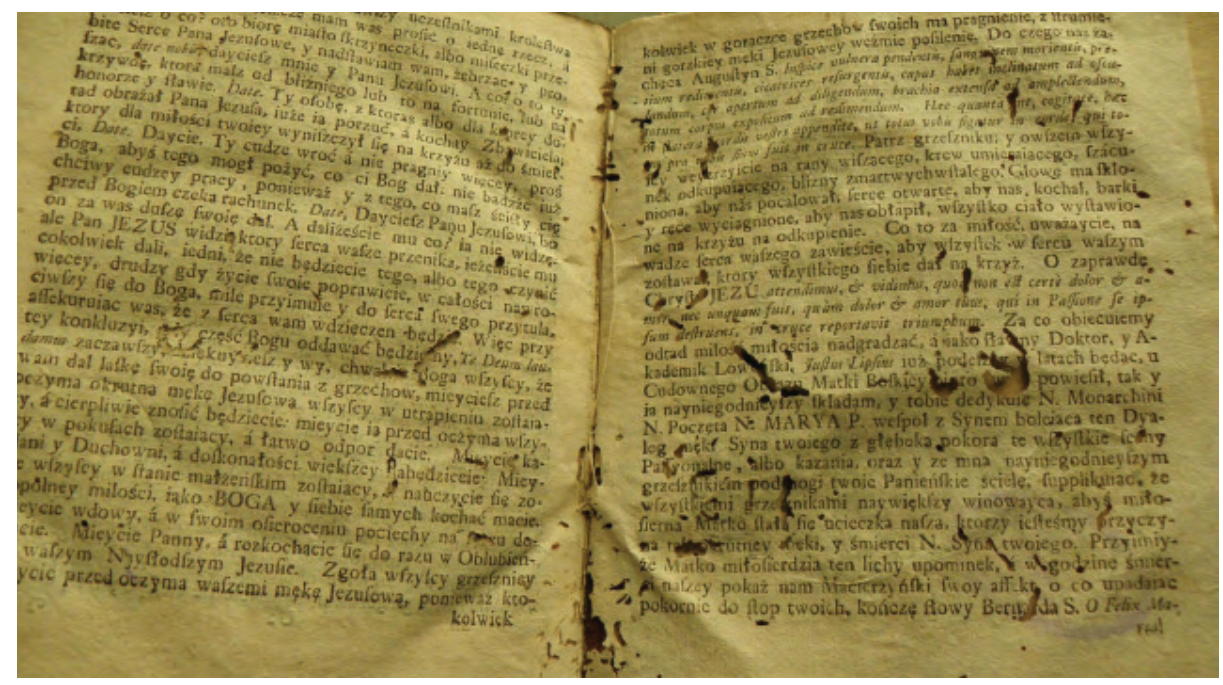

Fig. 2 - Larvae of S. paniceum feeding on paper burrow tunnels in book.

usually destroyed when a single tunnel was fully formed. Many characteristic emergence holes of the adults were found in the book bindings (Fig. 4) when larvae completed their development. Around books there was an enormous amount of dust (Fig. 5) as a result of larval feeding activity.

None of modern books kept in two rooms of the library was damaged by the drugstore beetle. Only old books were subject to pest infestation. It was estimated that about $80 \%$ old books kept in three rooms of the library were found more or less damaged by this pest. 


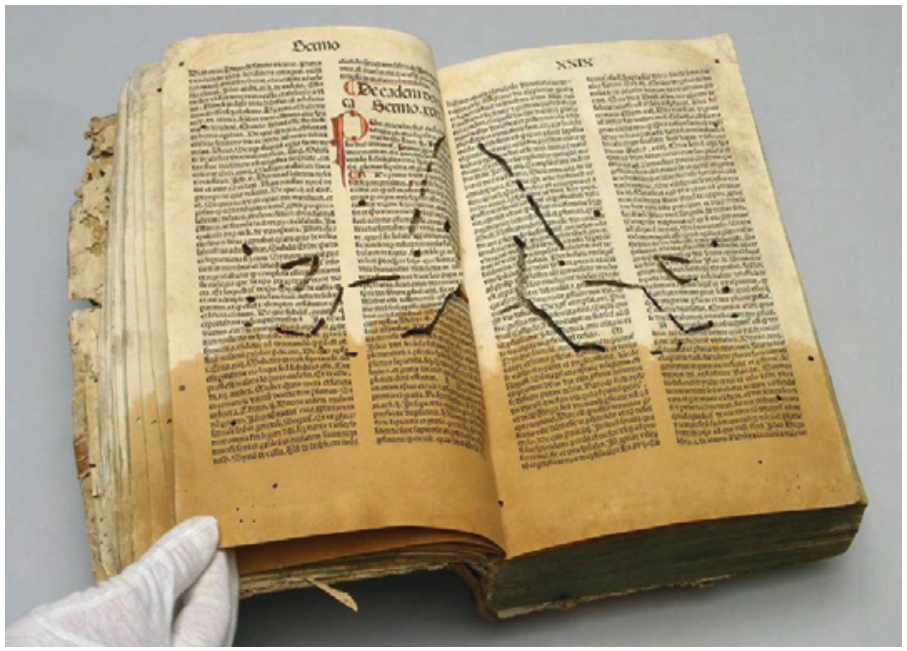

Fig. 3 - Tunnels in the book become larger as larvae grow.
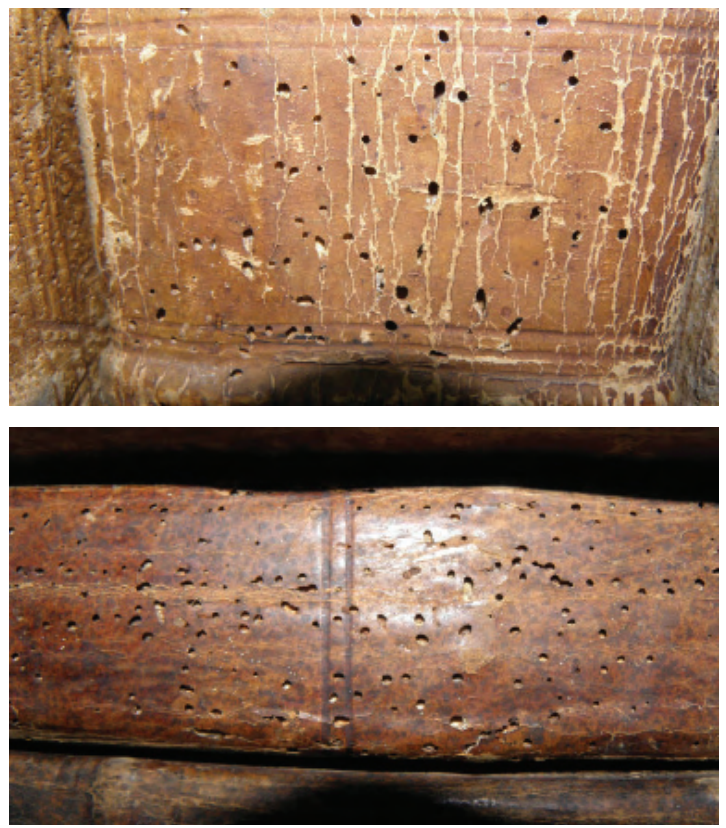

Fig. 4 - Emergence holes in book bindings. 


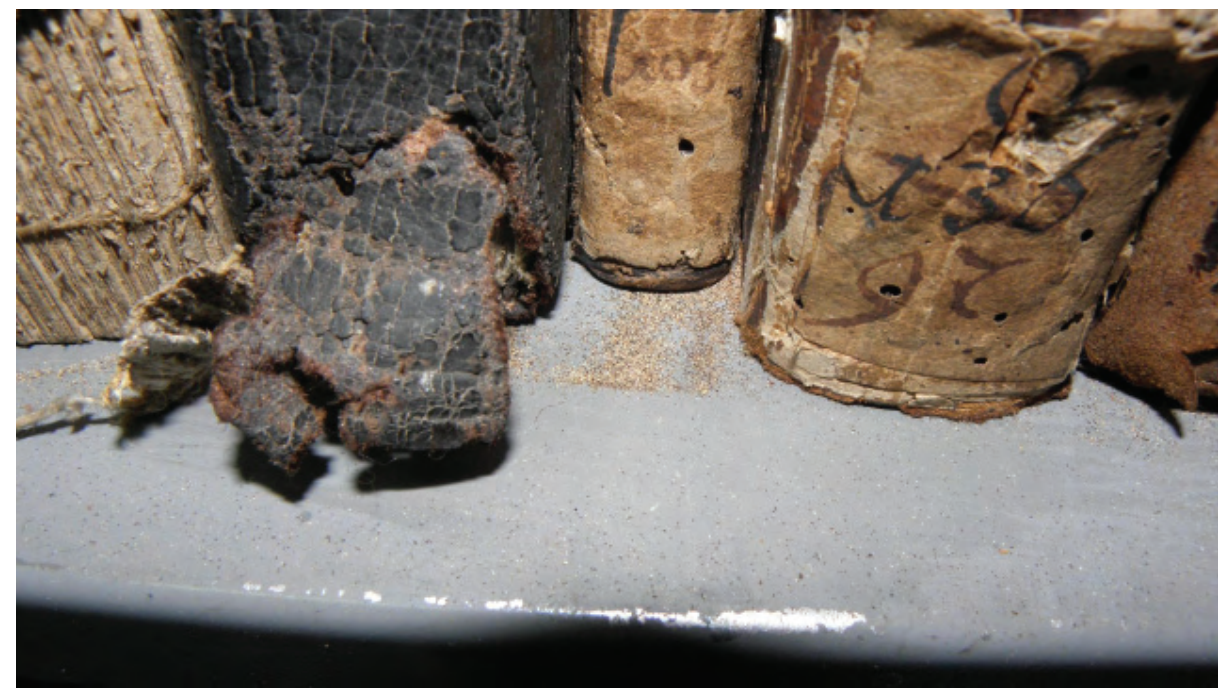

Fig. 5 - Dust around books as a result of larval activity.

\section{DISCUSSION AND CONCLUSIONS}

The drugstore beetle infests nearly any dry plant or animal material, and it has been reported from stored grain, dry bread, macaroni, black and red pepper, various spices and herbs, botanical collections, drugs, tobacco products, dried fruits and vegetables, textiles, leather, and books (Arbogast, 1991; Golebiowska \& Nawrot, 1976). Only larvae are responsible for damage of goods, as adults do not feed (Lefkovitch, 1967).

The drugstore beetle female lays about 75 eggs on the products (Arbogast, 1991), such as books, or near them. On hatching, larvae of $S$. paniceum borrow into the book, feeding on paper as they go. Often larvae feed on starch glue near book binding and/ or leather cover of book. After four to six instars, the larvae pupate in large cells near book binding.

The damage signs caused to the old books by the drugstore beetle were found to be similar to those done by the common furniture beetle to books in Israeli library (Wilamowski, 2008).

Some live adults of the pest were found around old books. Most tunnels in damaged books were old, but some of them were new tunnels with live larvae and pupae of the drugstore beetle, indicating the active infestation of books in the library. Therefore, the following Integrated Pest Management (IPM) Program and recommendations were 
suggested to the owners and curator of the library to control infestation and to avoid the continuation of the damage:

1) Keep the library room at the minimum temperature and humidity, and monitor the changes of climatic conditions there.

2) Improve insect-tightness of the library room and adjacent rooms.

3) Vacuuming the dust with live and dead insects that accumulated on the shelves to stop or limit the population growth of the pest as well the varied carpet beetle, $A n$ threnus verbasci L., and related species that feed upon dead insects.

4) Aerosol application (fogging) with dichlorvos ("Winylotox 1000") to reduce the exposed adult populations.

5) Install 2-3 insect light traps per each library room. They are effective in controlling adults as beetles positively respond to the UV light.

6) Apply the VELOXY technique (VEry Low OXYgen) or try biological method involving repeated releases of the parasitoid Lariophagus distinguendus (F.).

7) After these treatments install and maintain a monitoring system. Use pheromone traps for anobiids with stegobinone as a pheromone.

8) Damaged books, that are especially valuable, should be restored by a specialist.

9) Received books check for any sign of infestation, and refuse them if infested by the pest.

Treatment of books by freezing to $-30^{\circ} \mathrm{C}$ in order to kill developmental stages of the drugstore beetle (Nesheim, 1984) was refused by the owners and curator of the library. They did not agree that the valuable books must leave the library rooms.

Studies have shown that gaseous chemicals can cause harm to their operators, destroy the environment, and may damage rare antiquities and artifacts (Dawson, 1988; Florian, 1988). Therefore, fumigations with phosphine $\left(\mathrm{PH}_{3}\right)$ were not suggested as the gas could have unexpected side-effects on ink and paintings within the old books. In museums, the future for fumigation with traditional chemicals seems to be uncertain.

\section{REFERENCES}

Arbogast R.T., 1991 - Beetles: Coleoptera. In: Gorham R.J., Ecology and management of foodindustry pests. Ed. FDA Technical Bulletin, 4: 131-193.

Dawson J., 1988 - The effects of insecticides on museum artifacts and materials. In: Zycherman L.A. \& Schrock J.R. - A guide to museum pest control. Ed. Assoc. of Syst. Collections, Washington D. C.: 135-150.

FLoRIAN M.L., 1988 - Ethylene oxide fumigation: a literature review of the problems and interac tions with materials and substances in artifacts. In: Zycherman L.A. \& Schrock J.R., A guide to museum pest control. Ed. Assoc. of Syst. Collections, Washington D. C.: 151-158.

Golebiowska Z., NAwrot J., 1976 - Szkodniki magazynowe [Stored product pests]. PWRiL, Warszawa.

LefKovitch L.P., 1967 - A laboratory study of Stegobium paniceum (L.) (Coleoptera: Anobiidae). J. stored Prod. Res., 3: 235-249.

Nesheim K., 1984 - The Yale non-toxic method of eradication book-eating insects by deep-freezing. Restaurator, 1984: 147-164. 
SCHROCK J.R., 1988 - List of insect pests by material or apparent damage. In: Zycherman L.A. \& Schrock J.R., 1988 - A guide to museum pest control. Ed. Assoc. of Syst. Collections, Washington D. C.: 113-120.

Wilamowski A., Schnur H., Kessler I., Navarro S., 2008 - Anobium punctatum (Coleoptera, Anobiidae), a new pest of books in Israel. IOBC/wprs Bulletin, 40: 23-28.

Stanislaw Ignatowicz, University of Life Sciences-SGGW, Department of Applied Entomology, ul. Nowoursynowska 159, 02-787 Warszawa, Poland.

E-mail: ignatowiczst@yahoo.com

Krystyna JancZukowicz, Pest Control Company “Insectum-2”, ul. Dobrego Pasterza 67, 31-416 Krakow, Poland.

E-mail: biuro@insektum2.krakow.pl

Pawel Olejarski, Plant Protection Institute, ul. W. Wegorka 20, 60-318 Poznan, Poland.

E-mail: op68@wp.pl 